\title{
Competitiveness of the Sugarcane Cluster in Goianesia-GO, Brazil
}

\author{
Jhon Sebastian Castiblanco ${ }^{1} \&$ Alcido Elenor Wander $^{2}$ \\ ${ }^{1}$ Universidade Federal de Goias (UFG), Goiania-GO, Brazil \\ ${ }^{2}$ Embrapa Arroz e Feijão, Santo Antonio de Goias-GO, Brazil \\ Correspondence: Alcido Elenor Wander, Embrapa Arroz e Feijão, Santo Antonio de Goias, GO, CEP 75375-000, \\ Brazil. Tel: 55-62-3533-2116. E-mail: alcido.wander@embrapa.br
}

Received: July 10, 2016

Accepted: August 3, 2016

Online Published: August 31, 2016

doi:10.5539/mas.v10n11p255

URL: http://dx.doi.org/10.5539/mas.v10n11p255

The research is financed by Brazilian National Counsel of Technological and Scientific Development (CNPq).

\begin{abstract}
The present study aims to analyze the competitiveness of the chain of sugarcane cluster that is located in Goianesia (Goiás state, Brazil) and in nearby municipalities like Barro Alto, Santa Rita and Vila Propicio. It was used Michael Porter's Diamond of Competitiveness, which lets to study the competitiveness of a company, cluster or country, by four factors: demand conditions, factor conditions, context for firm strategy and rivalry and related and supporting industries. To build the Diamond of Competitiveness was used secondary and primary information, where the latter was collected by interviewing the key actors inside and outside the Jalles Machado, central company of the cluster analyzed. In terms of results they were found several interesting aspects that affect (positively and negatively) competitiveness of the cluster. It was identified, for instance, how investment in research and development, as well as the adoption of technology, are key for the central company of the cluster to facing the physical constraints of the Goianesian soil, and how this contribute to the cluster competitiveness against other actors that are in better conditions. In addition, the cooperation between cluster's stakeholders which makes the central company and its partners identify together the cluster's weaknesses and work on a solution- was identified as a key factor in creating competitive advantage. The paper presents the factors that affect both positively and negatively the competitiveness of Goianésia's cane sugar cluster, leaving available the necessary inputs for policy makers drawing strategies for improving the competitiveness of this cluster.
\end{abstract}

Keywords: diamond of competitiveness, cluster, stakeholder

\section{Introduction}

The sugarcane in Brazil is one of the better-organized agro industrial activities and one of the more traditional in the country. According to FAO (2015), for 2013 the cane occupied 9.8 million hectares in Brazil and reached a production of 739 million tons, which is nearly twice the area and the production of the second largest producer, India, which reached 5 million hectares and 341 million tons of cane that year. These figures make Brazil the main producer of this crop worldwide, positioning itself also as the largest exporter of sugar in the world, since in 2011 Brazil exported 63\% of world raw sugar (FAO, 2015).

This agro industrial activity has gained relevance in Goiás, which currently ranks as the second state with the largest sugarcane production in Brazil with $10 \%$ of national production, after São Paulo who leads the production with $57 \%$ of the total. In the state of Goiás stands out, among others, the municipality of Goianésia, which has turned an important sugarcane production cluster. This paper seeks to study the relationships between actors inside the value chain of sugarcane in the municipality of Goianésia (GO, Brazil) and its environment and in this sense to identify the actual and future competitiveness of the cluster. By studying these relationships, the study attempts to answer the question: what are the factors related to the competitiveness of the sugarcane cluster in Goianésia-GO, Brazil?

The study of this value chain is done in order to identify its potential regional, national and even internationally competitiveness, based on an analysis of its components, focusing on a microeconomic competitiveness approach but without ignoring some relevant macroeconomic aspects. The study, making use of the competitiveness diamond methodology, aims to be useful at the microeconomic level as it provides useful 
information to producers of sugarcane industry, so they can design strategies aimed at adding value to their production and to increase their productivity. It is also useful to public policy makers, so that they intervened at the macro level in order to ensure the increasing of cluster competitiveness bringing prosperity to both farmers and workers.

The study of the competitiveness of a chain requires the adoption of an epistemological position from where competitiveness will be understood. Both the methodology and the results of the study will vary depending on the concept of competitiveness to be used. In this sense it was been consulted some popular definitions of the concept as well as some schools of thought that have addressed the competitiveness from different angles, in order to recognize the most suitable for the study.

Among the best known definitions of competitiveness in the Brazilian agribusiness, it was found Callado's concept $(2011$, p. 24) which says that competition is " the sustainable ability to survive and preferably grow in competitive markets or in new markets through an information system able to fulfill the management needs derived from long-term planning". Another definition used in Brazil is the Haguenauer (1989, p. 13) which states that "competitiveness could be defined as the ability of an industry (or company) to produce goods with specific quality standards, required by certain markets, using resources at levels equal to or lower than those prevailing in such industries around the world during a certain period of time". The latter author states that the competitiveness definitions can be classified into two large groups consisting of those based on competitiveness as performance (ex-post concept) and those who focused on the competitiveness as efficiency (ex-ante concept).

In the present work it was decided to use the concept of competitiveness that presents the economist Michael Porter, which states that "prosperity is determined by the productivity of an economy" (...) "productivity supports high wages, a strong currency, and attractive returns to capital- and with them a high standards of living. Competitiveness, then, is measured by productivity" (Porter, 2008b, p. 44). The Porter's position is that an increase in productivity (of a company or a nation) leads to increased competitiveness. The real important thing, besides finding a complete definition of competitiveness applicable to any economy, is to identify the factors that increase productivity and promote the gains in competitiveness. As Porter mentioned (2008b, p. 44), "the central challenge for any economy is to create the conditions in which companies and employees throughout the economy can upgrade their productivity." When deciding to use this concept, the focus of this work is to recognize the factors related to the increasing of the competitiveness of the cluster studied.

Therefore, the next step is to identify what are the factors that affect competitiveness, to recognize these factors in the cluster studied. Fajnzylber (1988, apud Nunes, 2006, p. 89) recognizes a group of conditioning factors of international competitiveness, which can be summarized as:

- High levels of investment;

- Allocation of resources for investment in strategic sectors;

- Favorable labour legislation (flexibility, social security, education, quality of labour);

- Harmonious labor relations and constructive cooperation between the different economic, social and political actors;

- Organizational innovations (cooperative relations firms intra and inter firms);

- Educational system suitable for the formation of qualified human resources adequate for restructuring process with the incorporation of technical progress;

- Construction of comparative advantage with the absorption of technical progress;

- Use of policy instruments and institutional dimension.

Porter (2008a, p. 172) states that "according to prevailing thinking, labor costs, interest rates, exchange rates, and economies of scale are the most potent determinants of competitiveness", but he has shown that there are economies that are competitive even without possessing the characteristics "demanded" by orthodox economists. The limited view of orthodox economists about competitiveness requires identifying a more comprehensive approach on this issue. A more unorthodox insight about the factors affecting competitiveness is Schumpeter's theory of innovation. As Sledzik noted (2013, p. 90) "Schumpeter argued that anyone looking for profits have to innovate (...) Schumpeter believed that innovation is regarded as an essential driver of competitiveness and economic dynamics".

The relevance of innovation in relation to the competitiveness was taken decades later by Porter, who related the concept of innovation to productivity and competitiveness. According to him "the only meaningful concept of competitiveness at the national level is productivity" (Porter, 2008a, p. 176), and it always focuses on a few 
specific sectors or segments. Concerning to the firm, Porter states that "companies achieve competitive advantage through acts of innovation" (Porter, 2008a, p. 179).

As it recognizes the importance of productivity and innovation, Porter goes on to identify the factors that create these competitive generators. Here, the author assures that "macroeconomic competitiveness indicators create opportunities for productivity but are not sufficient for high productivity to emerge. Microeconomic competitiveness indicators have a direct impact on company productivity" (Porter, 2008b, p. 53).

Focused on competitiveness at the micro level, Porter studied the national business environment and find that this is explained by four factors that are responsible for competitiveness and constitute what he calls the diamond of competitiveness. These factors, which are shown in Figure 1, are demand industries, factor conditions, context for firm strategy and rivalry, relating and supporting industries. Those factors are the tool used in this work to study the competitiveness of the Goianesian sugarcane cluster.

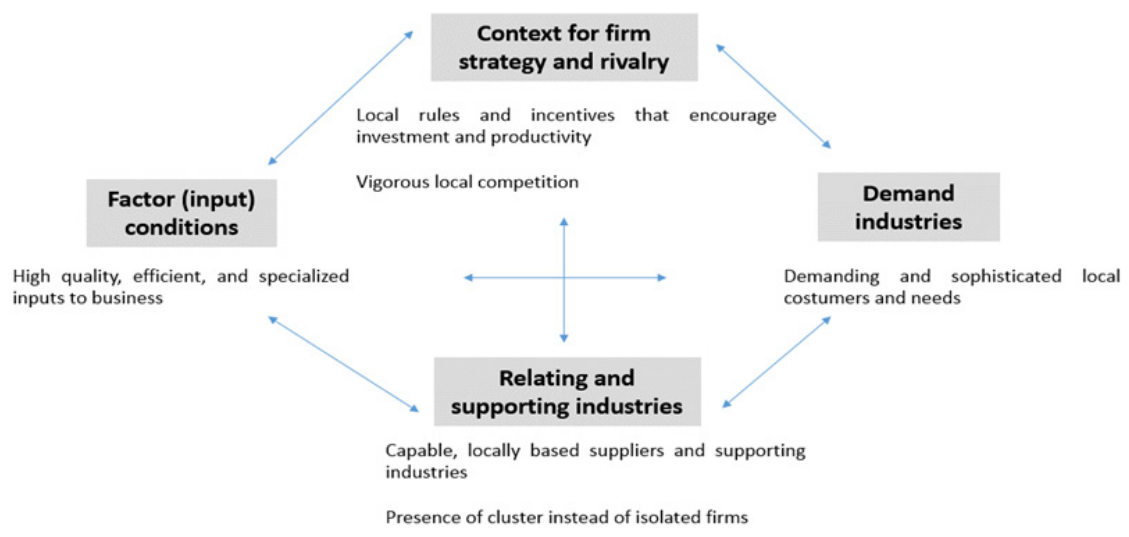

Figure 1. Diamond of competitiveness at the micro level

The objective is to analyze the competitiveness of the Goianesian sugarcane cluster, by constructing the diamond of competitiveness relative of that cluster. For this, the work is presented in four parts where this introduction conforms the first one. The methodology provides a second part while the results are presented on the third part. The discussion is presented in the final chapter.

\section{Method}

The present research project, classified as exploratory, qualitative and applied, was developed in the sugarcane cluster located in the municipality of Goianésia in the state of Goiás, Brazil. It is a case study on the sugarcane cluster of Goianesia-GO, Brazil. In this municipality took place two visits, the first in order to recognize the sugarcane chain value by identifying the processes and key stakeholders in each link in the chain, and the second in order to conduct key informant interviews to collect primary information that was used in the construction of the diamond of competitiveness.

The interviews focused on the cluster's central industry, the Jalles Machado company, which is the largest and most important industry of the region and which owns more than 40,000 hectares planted with sugarcane in Goianésia and nearby municipalities. In this company were interviewed five leaders and managers of the processing areas, planting and research, warehouse and inputs, market and competitors, and finance. Interviews were done exclusively to leadership area, who have more and most quality information. In addition to these actors in the cluster's central industry, three interviews were conducted with other actors, including a leading supplier of raw materials, an important research partner and a leading researcher in the field of Brazilian agro-energy.

Additional to the collection of primary information, and of equal importance to this, it was compiled secondary information to contribute in building the diamond of competitiveness and to corroborate or completed the testimony given by the respondents. In this case, they were consulted articles published by public organizations or researchers of the studied sector as the EPE (Energy Research Company) or FIEG (Federation of Industries of the State of Goiás), as well as information published on the website of organizations concerned with the sector 
like the SIFAEG (Ethanol Manufacturing Industry Union of the State of Goiás), or Novacana portal, among others.

The union of primary and secondary sources let to construct the diamond of competitiveness which, by its complexity, was divided into two parts, a cross-sectorial diamond and a cluster diamond. It was done in that way because some of the factors affecting the studied cluster are common to all or most Brazilian sugarcane producers, while others are particular to Goianésia.

Qualitative data of interviews and analysis of documents and materials were basis to build the diamond of the cluster.

\section{Results}

\subsection{Cross-Sectorial Diamond of Competitiveness}

Factor conditions

- Stands out in Brazil the high availability of arable land compared to other international producers of ethanol or sugar. However, it has been evident the presence of cultivation in areas not suitable for sugarcane.

- There is a huge burden represented by the level of indebtedness of the processing industries where $29 \%$ of them were in recovery with high leverage and $18 \%$ had no way to recover and must undergo mergers or acquisitions (Novacana, 2012). This scenario worsened by the increase that took the dollar against the real during most of 2015.

Demand industries

- The government has contributed historically to create a domestic ethanol demand with the launch of Pro-Alcohol program in 1975, the introduction of MEG blend (60\% hydrous ethanol, $34 \%$ methanol and $6 \%$ gasoline), the creation of flex-fuel engine in 2003, among others. These initiatives have acted as a huge incentive for the entire sugar industry (Montenegro, 2012, pp. 55-57).

- International demand has also attractive dynamics in the sugar market and, according to Ministry of Agriculture projections, it can be expected a continued growth in international sugar demand, especially in China, Algeria, Egypt, Malaysia and others (Montenegro, 2012, pp. 67-68).

- The high US energy demand is an opportunity, but trade restrictions in that country currently make difficult taking advantage of that opportunity, which could be useful in the medium or long term with the signing of a Free Trade Agreement with the US. According to Trevisan, Monteiro \& Silva (2015) the Brazilian government is interested in joining of new trading blocs and "until it doesn't build a broad agreement with the United States, Brazil will give priority to trade facilitation measures (with them)".

- The growth of demand for new goods that serve as energy sources in the form of biofuels and bioelectricity, is unquestionable. In the case of sugarcane, there are market opportunities like the development of second-generation ethanol, also known as lignocellulosic ethanol, which make attractive the cultivation of sugarcane for energy and biofuel markets (SIFAEG, 2015a).

- The demand is increasingly geared to value raw materials friendly to the environment. The sugarcane can be differentiated with other competing crops in world energy markets, because of its energy efficiency measured by generated units of energy compared to used units. In the case of sugarcane, life cycle analyzes indicate that this ratio of generation and energy consumption is 8 to 1 , while crops that compete directly with sugarcane to generate biofuels, such as corn has a relation of 1 to 1 (EPE, 2008, p. 9).

- The demand for ethanol can be affected by the global economic slowdown as it discourages the growth of the price of ethanol that is strongly linked to crude oil prices. According Plinio Nastari of Datagro, referring to the case of the national economy specifically, "the slowdown of the Brazilian economy is slowing the will of consumption of fuel and electricity" (SIFAEG, 2015b).

- The artificially low gas prices hinder the growth of ethanol prices.

Context for firm strategy and rivalry

- The existence of subsidies in some countries producers of ethanol and sugar distorts the quantities of sugarcane produced, pushing the market equilibrium. 
- In addition to the subsidies, some countries imposed tax rates to protect local producers against the entry of Brazilian products. For instance, the US imposes a fee per gallon of the Brazilian ethanol, creating an advantage for countries competitors of Brazil like those of the Caribbean Basin Initiative (CBI) in Central America (EPE, 2008, p. 25).

- The government's lack of clarity in gasoline prices create uncertainty in the sector and affect it directly. The partial removal of the collection of CIDE (Contribution of Intervention in the Economic Domain) on gasoline, generated troubles to ethanol for competing with fossil fuels in recent years.

- The growing role of some competitor countries has threatened the possibility of entry of Brazilian products in other markets. Montenegro (2012, p. 43) emphasizes the growth of exports of raw sugar from Thailand who has good climatic conditions for sugarcane production at a competitive cost, small domestic consumption and proximity to the Asian consumer markets.

Related and supporting industries

- The Brazilian sugarcane industry has sufficient organizations and research centers, public and private, working in technological innovation. There is a specialization in research by each of them, which makes it face different needs as well as specificities of each region of the sugarcane industry.

Figure 2 summarizes the factors affecting competitiveness, cross way for most sugarcane producers in Brazil. These factors should be added to the particular factors affecting the Goianesian sugarcane cluster for having a complete diagnosis of the cluster. These other factors will be exposed to continuing.

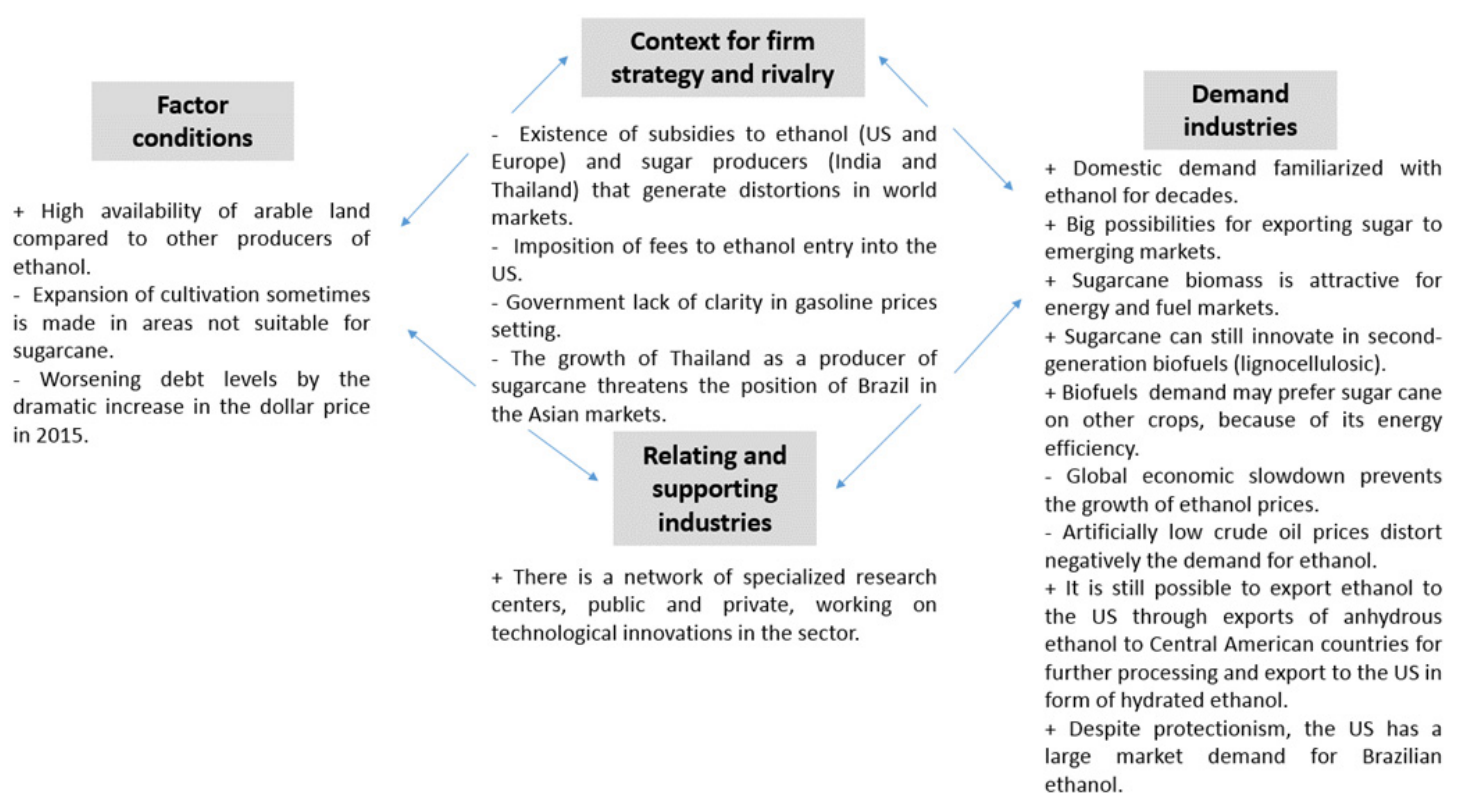

Figure 2. Cross-sectorial diamond of competitiveness of sugarcane in Brazil

\subsection{Cluster Diamond of Competitiveness}

Factor conditions

- Goianésia is located in a state that is at the center of the country where there is "easy flow of production to the large Brazilian centers" (Alves \& Wander, 2000, p. 10). This is an advantage for interior trade but also a disadvantage for exports since the municipality is far from the sea ports. This situation is even worse by the poor condition of the roads.

- The North-South Railway will create new options of transport to the products of the cluster. The project "planned the construction of 1,550 km, from Açailândia/MA to Anapolis/GO, in order to cross the states of Maranhão, Tocantins and Goiás. With the Law No. 11,772 of 2008 were incorporated into this layout the stretches of Barcarena/PA to Açailândia/MA and Ouro Verde/GO to Panorama/SP" (VALEC, 2015). At the present time, it has been built Palmas-Annapolis stretch (delivered in May 
2014) and is already operating Palmas/TO-Açailândia/MA stretch. The other parts are in stages less advanced, which means that Goianésia is still disconnected from seaports South and North.

- The GO-MG-SP ethanol pipeline project will integrate Goiás to Brazilian ethanol exports circuit. This project involves the construction of a logistics system covering Goiás, Minas Gerais and São Paulo. The Goiás municipalities that directly will receive the benefit of the system are Aparecida do Rio Doce, Itumbiara and Senador Canedo. The distance between Goianésia and Senador Canedo is less than 200 $\mathrm{km}$, in this sense Goianésia will be beneficiated, reducing its transportation costs from the ethanol required to be exported to São Paulo's terminal (PAC, 2015).

- Labour is scarce in the region both for cultivation and for the processing industry. However, the Jalles Machado has made efforts to reduce dependence on labour, by automating the agricultural link. In the process of irrigation, for example, the use of pivots allowed "reduce labour from 130 operators to 77" (Folha da cana, 2014c).

- Labour is not sufficiently specialized in the area. Nevertheless, the Jalles Machado has made a series of investments to training personnel, setting a competitive advantage. Examples are the public partnership established between Jalles Machado and SESI and SENAI (Folha da cana, 2014a); the creation of the Trainee Program in 2014 (Folha da cana, 2014b); the partnership with SENAR and the Rural Union of Goianésia which has trained 7,032 participants including employees of Jalles Machado and people in the community (Folha da cana, 2015a), among other initiatives.

- The agricultural suitability of Goianésia results in a disadvantage against the sugarcane leaders in Brazil. There is little presence of rain and poor soils in the region but are compensated with application of organic matter, correction made with straw, irrigation and "fertirrigation", among other things, that lets the company get high yields without privileged soil and climate.

- The Cerrado biome, in which is located Goianésia, has a high biodiversity, which can create opponents to the establishment of monocultures as that of sugarcane. However, it is recognized that it is preferable the sugarcane to cattle that was once typical in the region.

Demand industries

- The state of Goiás has an attractive demand for electricity supply from alternative sources due to extensive dry seasons, which hampers the power generation by hydroelectrics. The bagasse and sugarcane straw are great alternatives sources.

- The organic sugar demand does not grow on expected proportions and the pace of production will not support the low growth rate of the demand.

Context for firm strategy and rivalry

- The cluster has a structure characterized by an important spatial concentration of sugarcane plantation and industrial processing, because it has no great distances between the farms and the mill. In addition, there is proximity between service providers and the central company of the cluster.

- The cluster has an advantage over its competitors in relation to the use of sugarcane by-products. The use of bagasse to generate bioelectricity, for instance, is a differentiating factor in Goianésia. In addition, it makes use of the filter cake in the planting furrow, allowing higher productivity.

- The ICMS regime (tax on movement of goods and services) in Goiás has not the flexibility it has in other states like São Paulo (direct competitor), generating production overcosts (SIFAEG, 2015b).

- There are tax benefits and other economic benefits like the programs "Fomentar", "Produzir" or the credit given on the anhydrous ethanol, that are offered by the state of Goiás and partially reduce the disadvantages caused by the unfavorable ICMS.

- The central company of the cluster has implemented a technology leadership strategy investing significantly in the adoption and creation of technologies that favor the increasing cluster's productivity. This strategy includes a successful partnership policy with other stakeholders who identifies in Jalles Machado company a chance to test its innovations, generating benefits for all stakeholders.

Related and supporting industries

- The research environment of the cluster is favorable, since in addition to the Jalles Machado, a number of input suppliers, as well as research centers, are constantly working on innovations adapted to the cluster's needs. 
- Although the cluster has spatial concentration of production and service providers, there are no important input suppliers nearby the cluster, causing that several major inputs have to be brought in from other states or even countries.

- Both, suppliers of inputs and agricultural machinery are in the most supporting industries, but in neither case these suppliers are unique to the cluster, since they benefit the other producers of sugarcane in Brazil.

- The respondents of relating and supporting industries interviewed highlighted the quality of relations with the cluster's central industry, stating that this environment favors the technological development of the cluster.

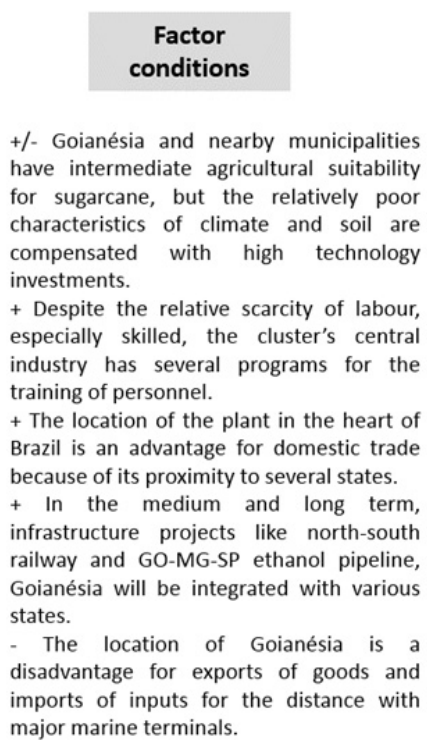

Figure 3. The Diamond of Competitiveness of the Goianésia’s Sugarcane Cluster

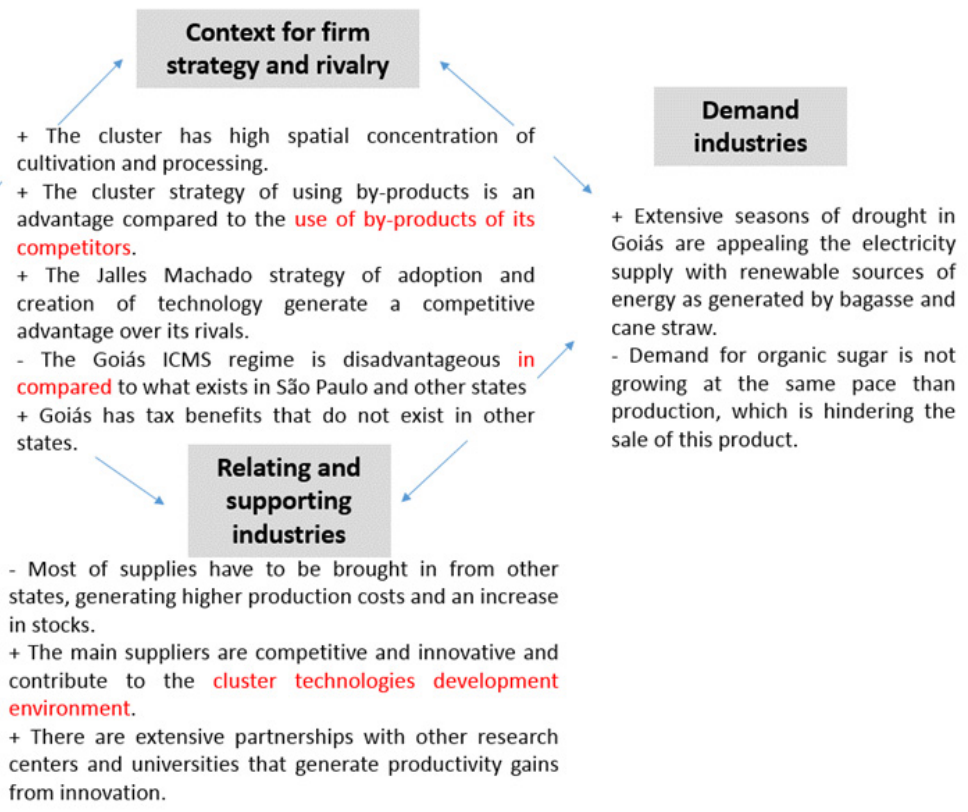

Relating and

supporting

industries

- Most of supplies have to be brought in from other states, generating higher production costs and an increase in stocks.

+ The main suppliers are competitive and innovative and contribute to the cluster technologies development environment.

+ There are extensive partnerships with other research centers and universities that generate productivity gains from innovation.

Diamond of competitiveness of the Goianésia's sugarcane cluster who was presented in this chapter, is summarized in Figure 3. Thus, figures 2 and 3 together, present in a synthetic way the factors, positive and negative, that affect Goianésia's sugarcane cluster classified according to the four components proposed by Porter.

\section{Discussion}

The purpose of this paper was to examine various aspects of the competitiveness of the Goianésia's sugarcane cluster, using the Porter's diamond of competitiveness. With this tool, several factors that affect positively and negatively the competitiveness of the cluster were founded. It was identified that some factors are common to most cane mills in Brazil, and they were included in a cross-sectorial diamond, but exists another that are exclusive of Goianésia's cluster (or that belongs to nearby municipalities or to Goiás), that were included in a cluster diamond. The union of these two diamonds shows all the factors affecting the competitiveness of the Goianesia's sugarcane cluster.

It was shown that this cluster despite having several opportunities for improvement can be regarded as competitive, especially in the domestic sugarcane scenario. Among the most remarkable features is the initiative of the Jalles Machado to have a policy of investing in science and technology, which contributes to the high productivity that typifies the production of the cluster. These high yields that characterize the production of both agricultural and industrial links (which has been recognized as among the most representative of the country), act as a shield against weaknesses like the little presence of rainfall and poor soil quality of the region, as well as from threats such as the virtual decrease in gasoline prices, or the high ICMS of the state of Goiás, letting the cluster being competitive without depending on measures generated by others. 
In addition, it was identified the way in which Jalles Machado has faced difficulties in the cluster as the scarce of labor in the region (especially qualified labor) through a staff training policy to improve the skill levels of workers. In addition, the Jalles Machado has implemented an automation policy of some agricultural activities that required a great number of workers, who is difficult to be supplied with the labour available in the region.

Another very important factor recognized is the harmony between its main actors. Relations between the Jalles Machado with its suppliers, as well as research centers, are characterized by the cooperation that is guided by common goals. The availability of Jalles Machado to serve as testing ground for new products, the high rates of adoption of technology of Jalles Machado and the initiative of suppliers of quality and research centers for respond to the cluster demands, are factors that create competitive advantages of immeasurable value to the region and the actors studied.

However, despite these qualities, which are not common in the Brazilian sugarcane industry, it is impossible to deny the existence of challenges arising from weaknesses of the cluster and from external factors that threaten the sector's competitiveness. The infrastructure of the state serves as an important bottleneck of the cluster as it hinders the flow of production to other states and, even worse, to other countries, due to the distance of Goianésia to Brazilian seaports and the poor condition of roads. Infrastructure projects that are in process will contribute, undoubtedly, to the competitiveness of the Goianésia's cluster but will only be available in the medium or long term, which is an important reason to keep the current area of influence of the cluster products to achieve flow the production without having to incur in additional transportation costs.

In addition, there is an urgent need to find new export markets for the production of organic sugar, since it has been showed that the growth of demand for this product is insufficient and will only be satisfactory by identifying new buyers or to create them through a strategy of promoting the goodness of organic sugar. That kind of strategy will only be possible by linking inter-institutional cooperation, including other domestic organic producers.

Therefore, for taking advantage of the factors identified from the diamond of competitiveness presented in this work, it will be necessary another studies that draw strategies to improve the competitiveness of the cluster. Strategies that will, if it is possible, link public and private actors to establish a continuous improvement policy that positions the Goianésia's sugarcane cluster as a national industry leadership and make it a more prominent actor internationally.

\section{Acknowledgments}

Authors thank to the Brazilian National Counsel of Technological and Scientific Development (CNPq) for financial support to this research.

\section{References}

Alves, N. C. G. F., \& Wander, A. E. (2010). Competitividade da produção de cana-de-açúcar no Cerrado Goiano. Informações Econômicas, 40(7), 5-17.

Callado, A. (Org.) (2011). Agronegócio. 3a ed. São Paulo, Atlas.

EPE. (2008). Perspectivas para o Etanol no Brasil. Retrieved from http://www.epe.gov.br/Petroleo/Documents/Estudos_28/Cadernos\%20de\%20Energia\%20-\%20Perspectiva $\% 20$ para $\% 20 \% \% 20$ etanol\%20no\%20Brasil.pdf

Fajnzylber, F. (1988). Competitividad Internacional: Evolución y Lecciones. Revista de La Cepal, 36, 7-24.

FAO. (2015). FAOSTAT database. Retrieved http://faostat.fao.org/site/567/DesktopDefault.aspx?PageID=567\#ancor

Folha da cana. (2014a). Cursos profissionalizantes são disponibilizados aos colaboradores e à comunidade. Folha da cana, 48, 10.

Folha da cana. (2014b). Jalles Machado aposta em desenvolvimento de Programa Trainee. Folha da cana, 48, 15.

Folha da cana. (2015a). Empresa investe na qualificação dos colaboradores. Folha da cana, 53, 19.

Haguenauer, L. (1989). Competitividade: Conceitos e Medidas: Uma resenha da Bibliografia recente com ênfase no caso brasileiro. Texto para discussão, 211, 1-20.

Montenegro, I. (Coord.) (2012). Cadeia Produtiva Sucroenergética. Goiânia, FIEG.

Novacana. (2012). Setor sucroalcooleiro chegará ao fundo do poço em 2014. Retrieved from 
http://www.novacana.com/n/industria/financeiro/setor-sucroalcooleiro-fundo-poco-2014-291112

PAC. (2015). Infraestrutura energética. Combustíveis renováveis. Sistema de logística de etanol. Retrieved from http://www.pac.gov.br/obra/2509

Porter, M. (2008a). On competition. Harvard Business School Publishing, Boston.

Porter, M. (2008b). Moving to a New Global Competitiveness Index. The Global Competitiveness Report 2008-2009. World Economic Forum, Génova.

SIFAEG. (2015a). Lignocelulose. Produção de etanol facilitada. Retrieved from http://www.sifaeg.com.br/noticias/lignocelulose.

SIFAEG. (2015b). Entrevista Plínio Nastari. 2015: ano de transição. Retrieved from http://www.sifaeg.com.br/noticias/entrevista-plinio-nastari

Sledzik, K. (2013). Schumpeter's View on Innovation and Entrepreneurship. Management Trends in Theory and Practice. Stefan Hittmar (Ed.), Faculty of Management, Science and Informatics, University of Zilina \& Institute of Management by University of Zilina.

Trevisan, C., Monteiro, T., \& Silva, Jr. A. (2015). Governo brasileiro defende acordo de livre comércio com os Estados Unidos. Estadão, 28 June. Retrieved from http://politica.estadao.com.br/noticias/geral,governo-brasileiro-defende-acordo-de-livre-comercio-com-os-e stados-unidos, 1715275

VALEC. (2015). Ações e programas - Ferrovias VALEC. Retrieved from http://www.valec.gov.br/acoes_programas/FNSFerroviaNorteSul.php

\section{Copyrights}

Copyright for this article is retained by the author(s), with first publication rights granted to the journal.

This is an open-access article distributed under the terms and conditions of the Creative Commons Attribution license (http://creativecommons.org/licenses/by/4.0/). 